\title{
HUBUNGAN KOMUNIKASI TERAPEUTIK PERAWAT DENGAN KECEMASAN PASIEN PRE OPERASI DI RUMAH SAKIT ADVENT MEDAN
}

\author{
Holmes Silalahi, Imanuel Sri Mei Wulandari \\ Fakultas Ilmu Keperawatan, Universitas Advent Indonesia, Jl. Kolonel Masturi, Bandung Barat, 40559, \\ Indonesia
}

E-mail:holmessilalahi376@yahoo.com

\begin{abstract}
Abstrak
Operasi merupakan peristiwa kompleks serta menegangkan sehingga menyebabkan banyak pasien mengalami kecemasan sebelum dioperasi. Namun banyak peneliti mengatakan bahwa kecemasan dapat diatasi melalui komunikasi terapeutik. Penelitian ini bertujuan untuk mencari hubungan komunikasi terapeutik perawat dengan kecemasan pasien pre operasi. Desain penelitian ini adalah cross sectional, dan sampel yang diambil melalui purposive sampling adalah sebanyak 34 orang. Instrumen yang digunakan adalah kuesioner komunikasi terapeutik perawat dan kuesioner tingkat kecemasan Zung Self Rating Anxiety Scale. Hipotesis diuji menggunakan pearson product moment, diperoleh nilai signifikansi sebesar 0,000 dengan nilai $r_{\text {hitung }}$ sebesar $-0,595^{* *}$. Nilai rata-rata persentase komunikasi terapeutik perawat berdasarkan persepsi pasien pre operasi berada pada kategori yang baik $(75,79 \%)$, sedangkan nilai rata-rata total skor kecemasan pasien pre operasi berada pada kategori yang normal $(39,06)$. Hasil penelitian ini menunjukkan hubungan signifikan antara komunikasi terapeutik perawat dengan kecemasan pasien pre operasi. Penulis menyarankan untuk dilakukan kajian yang lebih dalam tentang faktor-faktor yang memengaruhi komunikasi terapeutik perawat dan kecemasan pasien pre operasi.
\end{abstract}

Kata Kunci: Kecemasan, Komunikasi terapeutik perawat, Preoperasi

\begin{abstract}
The operation is complex and erratic condition, and it caused a lot of patient experienced anxiety before surgery. Many researchers say that anxiety can be overcome through communication therapeutic. The purpose of this study was to analyze the relationship between communication therapeutic nurses and anxiety in patients preoperative. This research methode is cross-sectional, involving 34 respondents through purposive sampling technique. The data collection technique uses a communication therapeutic questionnaire and Zung Self Rating Anxiety Scale questionnaire. Hypothesis analyzed using pearson product moment And obtained the value of significance 0,000 with $r$ count $-0,595^{* *}$. Based on the perception of patients preoperative, average value of the communication therapeutic nurses have good category $(75,79 \%)$, and anxiety in patients preoperative have normal category (score 39,06). The result showed that there is relationship between communication therapeutic nurses and anxiety in patients preoperative. Research suggestions are to explore more about factors that can influencing the communication therapeutic nurses and anxiety in patients preoperative.
\end{abstract}

Keywords: Anxiety, Communication therapeutic nurses, Preoperative 


\section{Pendahuluan}

Operasi atau pembedahan adalah tindakan pengobatan yang menggunakan teknik invasif dengan membuka atau menampilkan bagian tubuh yang akan ditangani melalui sayatan yang diakhiri dengan penutupan dan penjahitan luka (Talindong \& Minarsih, 2020; Pandiangan \& Wulandari, 2020). Tindakan operasi merupakan peristiwa kompleks dan menegangkan sehingga pengalaman operasi merupakan hal yang menakutkan bagi sebagian besar pasien dan terkadang belum dapat diterima secara positif oleh pasien (Ndani et al., 2018; Irwanto et al., 2020). Perioperative seringkali menimbulkan sikap yang yang berlebihan dari pasien yang berdampak pada kecemasan sehingga menyebabkan gangguan yang mengakibatkan tertundanya tindakan operasi (Margianti et al., 2019; Sutrisno \& Suroso, 2020).

Kecemasan merupakan satu kondisi dimana seseorang mengkhawatirkan sesuatu yang berlum terjadi dan belum tentu akan terjadi. Kecemasan juga disebut sebagai kekhawatiran yang tidak jelas dan berkaitan dengan perasaan yang tidak pasti serta tidak berdaya (Gunarsah, 2019; Sartika \& Pujiastuti, 2020). Masalah kecemasan merupakan reaksi emosional yang sering muncul pada pasien pre operasi. Kecemasan dianggap sebagai respon antisipasi pasien pre operasi terhadap suatu pengalaman yang dianggap sebagai suatu ancaman terhadap peran dalam kehidupan, integritas tubuh, dan kehidupan pasien (Anasril \& Husaini, 2020). Hasil penelitian Safitri \& Agustin (2020) pada 26 pasien pre opersai Sectio Caesarea menunjukkan bahwa 53,8\% (14 orang) mengalami kecemasan ringan, 38,5\% (10 orang) mengalami kecemasan sedang, dan $7,7 \%$ (2 orang) mengalami kecemasan berat. Hasil penelitian Daryanti \& Mardiana (2020) pada 28 pasien pre operasi hernia di RS. Salamun Bandung menunjukkan bahwa 42,3\% pasien mengalami kecemasan berat. Hasil penelitian Anggreny et al. (2019) pada 103 pasien pre operasi katarak menemukan bahwa $36,9 \%$ (38 orang) mengalami kecemasan ringan, $16,5 \%$ (17 orang) mengalami kecemasan sedang, dan 2,9\% (3 orang) mengalami kecemasan berat.
Kecemasan yang tidak segera diatasi akan menimbulkan dampak negatif bagi pasien pre operasi. Carnegie (2019) berpendapat bahwa kecemasan membuat seseorang gelisah, tetap terjaga, dan tidak tidur nyenyak. Hal ini didukung oleh hasil penelitian Rahman \& Pubian (2020) terhadap 90 pasien pre operasi, ditemukan 13 pasien pre operasi yang mengalami kecemasan ringan juga mengalami gangguan tidur ringan, dan 67 pasien pre operasi mengalami kecemasan berat juga mengalami gangguan tidur berat, peneliti menyimpulkan bahwa ada hubungan kecemasan dengan gangguan tidur pada pasien pre operasi.

Sutrisno \& Suroso (2020) mengatakan bahwa dampak kecemasan lainnya pada pasien pre operasi adalah meningkatkan tekanan darah, yang dapat menyebabkan penundaan waktu operasi untuk sementara waktu guna menstabilkan kondisi pasien. Hal ini sejalan dengan hasil penelitian Inayati \& Ayubbana (2017) menunjukkan bahwa pasien pre operasi yang memiliki kecemasan ringan hingga sedang mengalami peningkatan tekanan darah dalam kategori hipertensi sebesar $61,5 \%$, sedangkan pasien pre operasi yang memiliki tingkat kecemasan berat hingga berat sekali mengalami peningkatan tekanan darah dalam kategori hipertensi sebesar 58,8\%, peneliti menyimpulkan bahwa terdapat hubungan yang signifikan antara tingkat kecemasan dengan peningkatan tekanan darah.

Banyak faktor yang memengaruhi kecemasan pasien pre operasi diantaranya adalah tidak efektifnya komunikasi antara perawat dengan pasien (Ningsih \& Maryati, 2020). Komunikasi terapeutik adalah satu sarana untuk menjalin hubungan saling percaya antara perawat dan pasien sehingga dapat meningkatkan pelayanan keperawatan (Sulastri et al., 2019). Komunikasi terapeutik yang dilakukan perawat juga harus direncanakan dan berfokus pada kesembuhan pasien, sehingga dapat bermanfaat dan menjadi salah satu terapi nonfamakologi untuk mengatasi kecemasan pasien (Sulastri et al., 2019). Putri (2020) berpendapat bahwa melalui komunikasi terapeutik yang baik, selain dapat menimbulkan hubungan terapeutik perawat dengan pasien, juga dapat 
berdampak pada perbaikan psikologis pasien, termasuk dalam menghilangkan kecemasan.

Cholis et al. (2020) menjelaskan bahwa komunikasi terapeutik bermanfaat untuk membantu pasien dalam mengidentifikasi masalah sakit, mengurangi beban, serta mengurangi tingkat kecemasan. Untuk mengatasi kecemasan melalui komunikasi terapeutik, perawat mampu meningkatkan kepercayaan diri pasien yang berdampak pada pembentukan coping positif dan kesiapan dalam menghadapi berbagai kondisi yang mungkin terjadi pada pasien (Sulastri et al., 2019). Akan tetapi, perawat sebagai orang yang dekat dengan pasien dan selalu ada saat dibutuhkan oleh pasien, sering mengabaikan tugas dan tanggung jawab dalam melakukan komunikasi terapeutik yang baik kepada pasien (Agustina \& Oxyandi, 2018). Penelitian Hidayatullah et al. (2020) di ruang rawat inap Puskesmas Tapen Kabupaten Bondowoso menemukan bahwa 7 orang pasien mengeluh tidak puas dengan pelayanan yang di berikan perawat karena komunikasi terapeutik perawat yang kurang baik, yaitu perawat menggunakan bahasa medis yang tidak dimengerti oleh pasien serta menjelaskan kondisi pasien dengan cepat. Hasil penelitian Tridiyawati et al. (2020) menemukan bahwa 4 orang keluarga pasien berpersepsi bahwa komunikasi terapeutik perawat berada pada kategori kurang baik. Hasil penelitian Fandizal et al. (2020) juga menunjukkan bahwa 53,10\% dari 209 pasien kelas III mengeluh tidak puas dengan komunikasi terapeutik yang dilakukan oleh perawat di RS. Kepolisian Pusat Raden Soekanto.

Studi pendahuluan peneliti melalui wawancara terhadap tiga pasien pre operasi, mendapati bahwa dua pasien mengatakan takut dan cemas karena tindakan operasi yang akan dijalaninya, sedangkan sisanya mengatakan siap untuk dioperasi dengan alasan ingin cepat sembuh. Berdasarkan observasi peneliti pada rekam medis pasien, perawat dan dokter telah memotivasi pasien serta menjelaskan prosedur operasi yang akan akan dijalani.

Berdasarkan uraian di atas, peneliti merasa perlu untuk mengetahui gambaran komunikasi terapeutik perawat berdasarkan persepsi pasien, tingkat kecemasan pasien pre operasi, dan hubungan komunikasi terapeutik perawat dengan kecemasan pasien pre operasi di Rumah Sakit Advent Medan.

\section{Metode}

Penelitan ini merupakan penelitian deskriptif kuantitatif dengan pendekatan pengumpulan data cross sectional. Populasi dalam penelitian ini adalah pasien pre operasi. Responden penelitian diambil dengan menggunakan purposive sampling dengan kriteria inklusi yaitu pasien berjenis kelamin laki-laki dan perempuan, menjalani operasi elektif, memiliki kesadaran umum yang baik (GCS 15), dan mengalami skala nyeri 0-3 (010); serta kriteria eksklusi yaitu pasien cito operasi, dan pasien dengan anastesi lokal. Sehingga dalam kurun waktu pengumpulan data yang dimulai sejak tanggal 15 Desember 2020 hingga 31 Januari 2021, peneliti memperoleh responden sebanyak 34 orang.

Instrumen yang digunakan dalam penelitian ini adalah lembar kuesioner yang terdiri atas kuesioner komunikasi terapeutik perawat milik Anggarini (2015), dan kuesioner tingkat kecemasan Zung Self Rating Anxiety Scale/ZSAS yang diambil dari penelitian Hotijah (2019), dan penggunaannya telah berdasarkan ijin dari pemilik kuesioner .

Anggarini (2015) mengatakan bawah kuesioner komunikasi terapeutik perawat telah lulus uji validitas dan reliabilitas, dengan nilai total koefisien reliabilitas sebesar 0,88. Kuesioner ini terdiri atas 24 pertanyaan yang bersifat favorable dan terdiri atas tahap orientasi (9 item pertanyaan), tahap kerja ( 8 item pertanyaan), tahap terminasi ( 2 item pertanyaan), dan dimensi respon atau perilaku non verbal (5 item pernyataan). Pilihan jawaban yang disajikan adalah selalu, sering, kadang-kadang, jarang, dan tidak pernah. Metode skoring dilakukan pada pilihan jawaban, yaitu nilai 5 pada pilihan jawaban selalu, nilai 4 pada pilihan jawaban sering, nilai 3 pada pilihan jawaban kadangkadang, nilai 2 pada pilihan jawaban jarang, dan nilai 1 pada pilihan jawaban tidak pernah. Tabulasi data dilakukan melalui analisis deskriptif berdasarkan nilai persentasi, dan dikategorikan kepada skala kategori komunikasi terapeutik yaitu, 81$100 \%$ (sangat baik), $61-80 \%$ (baik), $41-60 \%$ (cukup baik), 21-40\% (kurang baik), dan $<20 \%$ (sangat kurang baik).

Hotijah (2019) mengatakan kuesioner kecemasan yang telah digunakan adalah kuesioner yang diadopsi dari buku milik 
Zung yaitu kuesioner Zung Self Rating Anxiety Scale/ZSAS. ZSAS memiliki nilai konsistensi internal (alpha crounbach) sebesar 0,85 dan nilai total koefisien reliabilitas sebesar 0,79. Kuesioner ini memiliki 20 item peryataan yang terdiri atas pernyataan favorabel sebanyak 6 item dan pernyataan unfavorabel sebanyak 14 item, disertai dengan pilihan jawaban selalu, sering, kadang-kadang, dan tidak pernah. Metode skoring dilakukan pada pilihan jawaban pernyataan favorable, yaitu nilai 1 pada pilihan jawaban selalu, nilai 2 pada pilihan jawaban sering, nilai 3 pada pilihan jawaban kadang-kadang, dan nilai 4 pada pilihan jawaban tidak pernah. Sedangkan skoring pada pilihan jawaban pernyataan unforabel adalah nilai 4 pada pilihan jawaban selalu, nilai 3 pada pilihan jawaban sering, nilai 2 pada pilihan jawaban kadang-kadang, dan nilai 1 pada pilihan jawaban tidak pernah. Tabulasi data dilakukan melalui analisis deskriptif berdasarkan nilai total skor, dan dikategorikan berdasarkan skala kategori kecemasan yaitu, skor 20-44 adalah kecemasan normal, skor 45-59 adalah kecemasan ringan hingga sedang, skor 60-74 adalah kecemasan berat, dan skor $>75$ adalah kecemasan ekstrim.

Uji normalitas dengan menggunakan uji Shapiro-Wilk perlu dilakukan sebelum pengujian hipotesis. Sugiyono (2018) menjelaskan bahwa dasar pengambilan keputusan dilakukan berdasarkan nilai signifikansi, yaitu jika nilai signifikansi lebih besar dari 0,05 maka distribusi dari populasi adalah nomal. Data yang memiliki distribusi normal, dapat dilakukan uji hipotesis dengan menggunakan uji statistik parametrik Pearson Product Moment dengan menggunakan aplikasi SPPS (Statistical Package for the Social Sciences).

Kriteria uji hipotesis penelitian dilakukan dengan melihat nilai signifikansi, yaitu $\mathrm{H}_{0}$ ditolak jika nilai signifikansi $>0,05$. Tingkat keeratan hubungan antara kedua variabel penelitian dapat dilihat melalui nilai $\mathrm{r}$ hitung, yaitu nilai $r$ hitung 0,00-0,199 diinterpretasikan pada hubungan yang sangat lemah, nilai $r$ hitung 0,20-0,399 diiterpretasikan pada hubungan lemah, nilai $r$ hitung 0,40-0,599 diiterpretasikan pada hubungan sedang, nilai $r$ hitung 0,60-0,799 diiterpretasikan pada hubungan kuat, dan nilai $r$ hitung 0,80-1,000 diiterpretasikan pada hubungan sangat kuat (Sugiyono, 2018). Sugiyono menambahkan bahwa jika nilai $r$ memiliki nilai negatif maka terdapat hubungan yang terbalik antara variabel $\mathrm{X}$ dan variabel $\mathrm{Y}$, sedangkan jika nilai $\mathrm{r}$ hasilnya positif maka terdapat hubungan yang searah antara variabel $\mathrm{X}$ dan variabel $\mathrm{Y}$.

Penelitian ini dilakukan sejak tanggal 15 Desember 2020 hingga 31 Januari 2021, di Rumah Sakit Advent Medan, Jl. Gatot Subroto No.Km 4, Sei Sikambing D, Kec. Medan Petisah, Kota Medan, Sumatera Utara. Penelitian ini sudah lulus uji etik dengan nomor 121/KEPK-FIK.UNAI/EC/XI/20 dan sudah mendapat surat izin dari pihak Rumah Sakit Advent Medan dengan nomor 044/DANotulen/RSAM/XII/2020/2020-210.

\section{Hasil}

Peneliti telah memastikan bahwa 34 responden telah mengisi kuesioner penelitian sesuai dengan petunjuk pengisian dan terisi lengkap. Berikut ini ditampilkan hasil tabulasi data penelitian dalam bentuk tabel dan nasrasi.

Tabel 1. Karakteristik Data Responden

\begin{tabular}{|c|c|c|c|}
\hline \multicolumn{2}{|c|}{ Karakteristik } & \multirow{2}{*}{$\frac{\mathbf{N}}{12}$} & \multirow{2}{*}{$\frac{\%}{35,3}$} \\
\hline Jenis & Laki-laki & & \\
\hline Kelamin & Perempuan & 22 & 64,7 \\
\hline \multirow[t]{6}{*}{ Usia } & 18 - 26 Tahun & 6 & 17,6 \\
\hline & 27 - 35 Tahun & 17 & 50 \\
\hline & 36 - 44 Tahun & 3 & 8,8 \\
\hline & 45 - 53 Tahun & 2 & 5,9 \\
\hline & 54 - 62 Tahun & 3 & 8,8 \\
\hline & $63-71$ Tahun & 3 & 8,8 \\
\hline Pendidikan & SMA & 18 & 52,9 \\
\hline \multirow[t]{3}{*}{ Terakhir } & Diploma I & 1 & 2,9 \\
\hline & Diploma III & 6 & 17,6 \\
\hline & $\mathrm{S} 1$ & 9 & 26,5 \\
\hline Sistem & Gastrointestinal & 4 & 11,8 \\
\hline yang akan & Genitourinari & 7 & 20,6 \\
\hline \multirow{3}{*}{ Dioperasi } & Integumen & 1 & 2,9 \\
\hline & Reproduksi & 18 & 52,9 \\
\hline & Muskuloskeletal & 4 & 11,8 \\
\hline Nama & Aff implant & 1 & 2,9 \\
\hline Tindakan & Appendictomy & 4 & 11,8 \\
\hline \multirow[t]{7}{*}{ Operasi } & Debridement & 2 & 5,9 \\
\hline & OREF & 1 & 2,9 \\
\hline & Sectio caesarea & 17 & 50 \\
\hline & TURP & 4 & 11,8 \\
\hline & $\begin{array}{l}\text { Uteroscopy dan } \\
\text { sacshe }\end{array}$ & 1 & 2,9 \\
\hline & URS & 2 & 5,9 \\
\hline & Wide excisi & 2 & 5,9 \\
\hline Jenis & General & 2 & 5,9 \\
\hline
\end{tabular}




\begin{tabular}{llll}
\hline Anastesi & Spinal & 32 & 94,2 \\
\hline
\end{tabular}

Informasi karakteristik responden yang diperoleh dari tabel 1 menunjukkan pasien pre operasi berjenis kelamin perempuan 22 orang $(64,7 \%)$ sedangkan sisanya adalah lakilaki 12 orang $(35,3 \%)$. Usia 27-35 Tahun berjumlah 17 orang (50\%), 18-26 Tahun sebanyak 6 orang $(17,6 \%)$, usia 36-44 Tahun sebanyak 3 orang $(8,8 \%)$, usia $45-53$ Tahun sebanyak 2 orang $(5,9 \%)$, usia 54-62 Tahun sebanyak 3 orang $(8,8 \%)$, dan usia 63-71 Tahun sebanyak 3 orang $(8,8 \%)$. Karateristik reponden berdasarkan pendidikan terakhir, SMA berjumlah 18 orang (52,9\%), Diploma I sebanyak 1 orang (2,9\%), Diploma III sebanyak 6 orang $(17,6 \%)$, dan Stratum 1 sebanyak 9 orang (26,5\%). Responden yang akan menjalani operasi pada sistem reproduksi berjumlah 18 orang $(52,9 \%)$, sistem genitourinari berjumlah 7 orang $(20,6 \%)$, sistem integument berjumlah 1 orang $(2,9 \%)$, sistem gastrointestinal berjumlah 4 orang $(11,8 \%)$, dan sistem musculoskeletal berjumlah 4 orang (11\%). Tindakan operasi yang akan dijalani yaitu Sectio Caesarea sebanyak 17 orang (50\%); operasi aff implant, uteroscopy dan sacshe, serta OREF/Open Reduction External Fixation masing-masing sebanyak 1 orang (2,9\%); appendectomy dan TURP/Transurethral Resection of the Prostate masing-masing sebanyak 4 orang (11,8\%); debridement, URS/Ureteroscopic Lithotripsy, dan wide excisi masing-masing sebanyak 2 orang $(5,9 \%)$. Responden yang akan mendapatkan anastesi general berjumlah 2 orang $(5,9 \%)$, dan anastesi spinal 32 orang $(94,2 \%)$.

Tabel 2. Gambaran Komunikasi Terapeutik Perawat

\begin{tabular}{lcc}
\hline \multicolumn{1}{c}{ Kriteria } & $\mathbf{N}$ & $\mathbf{\%}$ \\
\hline Sangat & 16 & 47,1 \\
Baik & & \\
Baik & 13 & 38,2 \\
Cukup & 4 & 11,8 \\
Baik & & \\
Kurang & 1 & 2,9 \\
Baik & & \\
Total & 34 & 100 \\
\hline
\end{tabular}

Tabel 3. Tahap Komunikasi Terapeutik

\begin{tabular}{cccc}
\hline Tahap & $\begin{array}{c}\text { Min } \\
(\%)\end{array}$ & $\begin{array}{c}\text { Mak } \\
(\%)\end{array}$ & $\begin{array}{c}\text { Rata- } \\
\text { rata } \\
(\%)\end{array}$ \\
\hline
\end{tabular}

\begin{tabular}{lccc}
\hline $\begin{array}{l}\text { Tahap } \\
\text { Orientasi } \\
\text { Tahap }\end{array}$ & 36 & 100 & 74 \\
Kerja & 38 & 100 & 77,71 \\
$\begin{array}{l}\text { Tahap } \\
\text { Terminasi }\end{array}$ & 20 & 100 & 77,94 \\
$\begin{array}{l}\text { Dimensi } \\
\text { Sikap dan }\end{array}$ & 40 & 100 & 74,82 \\
$\begin{array}{l}\text { Perilaku } \\
\text { Total rata-rata }\end{array}$ & 45 & 97 & 75,79 \\
\hline
\end{tabular}

Tabulasi data pada tabel 2 menunjukkan persepsi pasien pre operasi terhadap komunikasi terapeutik. Peneliti mendapati bahwa $47,1 \%$ (16 orang) pasien pre operasi memiliki persepsi bahwa perawat memiliki komunikasi terapeutik yang sangat baik, $38,2 \%$ (13 orang) berpersepsi bahwa perawat memiliki komunikasi terapeutik yang baik, $11,8 \%$ (4 orang) berpersepsi bahwa perawat memiliki komunikasi terapeutik yang cukup baik, dan $2,9 \%$ (1 orang) pasien pre operasi memiliki persepsi bahwa perawat terapeutik yang kurang baik.

Informasi tabulasi data pada tabel 3 menunjukkan total rata-rata persentase dari 34 pasien pre operasi terhadap komunikasi terapeutik perawat adalah sebesar $75,79 \%$, dimana total rata-rata nilai minimum yang diperoleh adalah $45 \%$ dan total rata-rata maksimum yang diperoleh adalah 97\%. Berdasarkan tahap-tahap komunikasi terapeutik perawat, tahap orientasi mendapat nilai rata-rata sebesar $74 \%$ dengan nilai minimum sebesar $36 \%$ dan nilai maksimum sebesar $100 \%$. Tahap kerja mendapat nilai rata-rata sebesar $77,71 \%$ dengan nilai minimum sebesar $38 \%$ dan nilai maksimum sebesar 100\%. Tahap terminasi mendapat nilai rata-rata sebesar $77,94 \%$ dengan nilai minimum sebesar $20 \%$ dan skor maksimum sebesar $100 \%$. Dimensi sikap dan perilaku mendapat nilai rata-rata sebesar $74,82 \%$, dengan nilai minimum sebesar $40 \%$ dan nilai maksimum sebesar $100 \%$.

Berdasarkan analisis data di atas, identifikasi masalah pertama tentang gambaran komunikasi terapeutik perawat dijawab dengan menggunakan nilai total rata-rata persentasi yaitu sebesar $75,79 \%$ yang berada pada kategori baik. Dengan demikian dapat diartikan bahwa pasien pre operasi berpersepsi bahwa mayoritas perawat di Rumah Sakit Advent Medan memiliki komunikasi terpeutik yang baik. 
Tabel 4. Tingkat Kecemasan Pasien Pre Operasi

\begin{tabular}{lcc}
\hline \multicolumn{1}{c}{ Kriteria } & N & \% \\
\hline Kecemasan Normal & 30 & 88,2 \\
Kecemasan Ringan & 4 & 11,8 \\
hingga Sedang & & \\
Kecemasan Berat & 0 & 0 \\
Kecemasan Ekstrim & 0 & 0 \\
Total & 34 & 100 \\
\hline
\end{tabular}

Tabel 5. Skor Rata-rata Komunikasi Terapeutik Perawat

\begin{tabular}{lccc}
\hline Kriteria & $\begin{array}{c}\text { Skor } \\
\text { Min. }\end{array}$ & $\begin{array}{c}\text { Skor } \\
\text { Mak. }\end{array}$ & $\begin{array}{c}\text { Skor } \\
\text { Rata- } \\
\text { rata }\end{array}$ \\
\hline $\begin{array}{l}\text { Kecemasan } \\
\text { pasien } \\
\text { pre operasi }\end{array}$ & 33 & 48 & 39,06 \\
\hline
\end{tabular}

Tabel 4 menunjukkan kecemasan pasien pre operasi. 88,2\% (30 orang) pasien yang akan menjalani operasi mengalami kecemasan yang normal, sedangkan yang lainnya mengalami kecemasan yang ringan hingga sedang (4 orang $/ 11,8 \%)$. Dan tidak ada pasien yang mengalami kecemasan yang berat hingga ekstrim. Informasi data pada tabel 5 menunjukkan bahwa nilai skor ratarata kecemasan dari 34 pasien pre operasi adalah sebesar 39,06, dimana diantara pasien pre operasi ditemukan skor minimum sebesar 33 dan skor maksimum sebesar 48

Berdasarkan analisis data di atas, identifikasi masalah kedua tentang gambaran kecemasan pasien pre operasi dijawab dengan menggunakan skor rata-rata yaitu sebesar 39,06 yang berada pada kategori normal. Dengan demikian dapat diartikan bahwa sebagian besar pasien pre operasi di Rumah Sakit Advent Medan memiliki kecemasan yang normal.

Tabel 6. Uji Normalitas Data

\begin{tabular}{lccc}
\hline \multicolumn{1}{c}{ Variabel } & \multicolumn{3}{c}{ Shapiro-Wilk } \\
& Statistic & df & Sig. \\
\hline $\begin{array}{l}\text { Komunikasi } \\
\text { terapeutik }\end{array}$ & 0,948 & 34 & 0,104 \\
$\begin{array}{l}\text { Kecemasan } \\
\text { pasien } \\
\text { pre operasi }\end{array}$ & 0,965 & 34 & 0,341 \\
\hline
\end{tabular}

Tabel 6 menunjukkan nilai uji normalitas data dengan Shapiro-Wilk. Diperoleh nilai signifikansi sebesar 0,104 pada variabel komunikasi terapeutik perawat dan nilai signifikansi sebesar 0,341 pada variabel kecemasan pasien pre operasi. Nilai signifikansi tersebut menunjukkan bahwa data dalam penelitian ini memiliki sebaran yang normal. Sehingga uji hipotesis dapat dilakukan dengan menggunakan statistik parametrik Pearson Product Moment. Hasil uji korelasi dengan menggunakan bantuan aplikasi SPSS, ditampilkan pada tabel 7 berikut ini:

Tabel 7. Korelasi Komunikasi Terapeutik Perawat dengan Kecemasan Pasein Pre Operasi

\begin{tabular}{llll}
\hline \multicolumn{1}{c}{ Variabel } & $\mathbf{N}$ & r hitung & Sig. \\
\hline $\begin{array}{l}\text { Komunikasi } \\
\text { terapeutik } \\
\text { perawat }\end{array}$ & & & \\
$\begin{array}{l}\text { Kecemasan } \\
\text { pasien pre } \\
\text { operasi }\end{array}$ & 34 & $-0,595^{* *}$ & 0,000 \\
\hline
\end{tabular}

Tabel 7 menunjukkan nilai $\mathrm{r}$ hitung sebesar 0,595 dan nilai signifikansi sebesar 0,000 $(p<0,05)$. Nilai $\mathrm{r}$ hitung dan yang diperoleh menyebabkan penolakan pada Ho dan penerimaan $\mathrm{Ha}$, yang artinya terdapat hubungan signifikan antara komunikasi terapeutik perawat dengan kecemasan pasien pre operasi. Hubungan yang dimaksud adalah hubungan yang sedang dan negatif.

\section{Pembahasan}

Penelitian ini dilakukan berdasarkan persepsi pasien, dan pasien memberikan penilaian kepada perawat secara general. Penelitian ini menemukan bahwa secara keseluruhan perawat di Rumah Sakit Advent Medan memiliki komunikasi terapeutik yang baik. Meskipun demikian, peneliti menemukan adanya kemampuan yang cukup dan kurang dalam jumlah kecil diantara perawat. Peneliti juga menemukan nilai yang kurang baik pada tahap orientasi, tahap kerja, tahap termiasi, serta dimensi sikap dan perilaku perawat.

Nanda (2018) mengatakan bahwa komunikasi yang intens akan terjalin antara pasien dengan petugas kesehatan terutama pada pasien rawat inap, karena pasien harus berada di ruang rawat inap lebih dari 24 jam untuk mendapat asuhan keperawatan yang berkesinambungan. Kemampuan berkomunikasi secara efektif merupakan 
standar pembangunan dan pemeliharaan ruang kerja yang sehat, serta sebagai suatu alat untuk mencapai hubungan yang helpinghealing relationship antara pasien dan perawat (Kusmiran, 2017).

Penelitian ini sejalan dengan penelitian Wianti (2017) yang menunjukkan bahwa rata-rata perawat saat ini telah mampu melakukan komunikasi terapeutik dengan baik, akan tetapi masih diperlukannya perbaikan sehingga perawat dapat lebih meningkatkan kemampuannya dalam berkomunikasi secara efektif. Suyitno et al. (2017) dan Handayani \& Armina (2017) menjelaskan bahwa ada berbagai faktor yang dapat memengaruhi komunikasi terapeutik perawat, diantaranya adalah pengetahuan, lama masa kerja, dan kecerdasan emosi perawat. Kurangnya penggunaan sumber komunikasi yang tepat; kurangnya perencanaan dalam berkomunikasi; penampilan; sikap; perbedaan persepsi; kondisi mental/fisik yang kurang baik; perbedaan bahasa; kondisi lingkungan; perbedaan latar belakang, nilai, sosial budaya dan bahasa juga dapat memengaruhi komunikasi terapeutik perawat (Mundakir, 2016).

Penelitian ini juga menghasilkan gambaran tingkat kecemasan pasien pre operasi di Rumah Sakit Advent Medan, yaitu mayoritas pasien pre operasi mengalami kecemasan yang normal. Hasil penelitian ini sejalan dengan hasil penelitian Asnuriyati \& Wahyu (2019) yang menemukan bahwa mayoritas pasien pre operasi memiliki kecemasan yang normal hingga bebas dari kecemasan. Berbeda dengan hasil penelitian yang dilakukan oleh Margianti et al. (2019), yaitu tidak menemukan kecemasan normal diantara pasien pre operasi, tetapi didapati kecemasan yang ringan, sedang, hingga kecemasan yang berat.

Gangguan kecemasan merupakan gangguan psikiatri yang paling sering ditemukan dan tidak dapat dihindari (Rismawan et al., 2019). Dalam penelitian ini masih ditemukan dalam jumlah kecil kecemasan ringan hingga sedang pada pasien pre operasi di Rumah Sakit Advent Medan. Kecemasan ringan dapat menyebabkan individu menjadi waspada dan meningkatkan lapang persepsinya, sehingga pengalaman tersebut menjadi motivasi belajar dan menghasilkan pertumbuhan serta kreativitas, sedangkan kecemasan sedang dapat mempersempit lapang persepsi individu
(Annisa \& Ifdil, 2016). Vellyana et al. (2017) dan Palla et al. (2018) menjelaskan bahwa kecemasan pada pasien pre operasi dapat disebabkan oleh berbagai faktor yaitu, usia, jenis kelamin, status ekonomi, pengetahuan, dukungan keluarga, komunikasi dan sikap perawat, serta jenis tindakan medis yang akan dijalani.

Hasil uji korelasi penelitian ini menunjukkan bahwa adanya hubungan sedang, signifikan, dan negatif antara komunikasi terapeutik perawat dengan kecemasan pasien pre operasi di Rumah Sakit Advent Medan. Hubungan yang bernilai negatif menunjukkan hubungan yang terbalik diantara kedua variabel penelitian, yaitu jika komunikasi terapeutik perawat mengalami peningkatan maka akan terjadi penurunan kecemasan pada kecemasan pasien pre opersi, dan sebaliknya jika komunikasi terapeutik perawat mengalami penurunan maka akan terjadi peningkatan kecemasan pada pasien pre opersi. Hubungan yang sedang mengartikan bahwa adanya variabel-variabel lain diluar penelitian yang memengaruhi komunikasi terapeutik perawat dan kecemasan pasien pre operasi.

Komunikasi terapeutik merupakan bentuk komunikasi interpesonal antara pasien dengan perawat (Nanda, 2018). Interaksi perawat melalui komunikasi terapeutik dianggap pasien sebagai satu kesempatan untuk berbagi perasaan, pengetahuan, dan informasi tentang pelaksanaan operasi agar dapat berjalan lancar tanpa ada kendala, sehingga berdampak pada penurunan kecemasan pada pasien (Sutrisno \& Suroso, 2020; Cholis et al., 2020; Basra et al., 2017). Melalui komunikasi terapeutik perawat juga mampu meningkatkan kepercayaan diri pasien yang berdampak pada pembentukan coping positif dan kesiapan dalam menghadapi berbagai kondisi yang mungkin terjadi pada pasien (Sulastri et al., 2019).

Hasil penelitian ini sejalan dengan hasil peneletian Mamahit et al. (2019) dan Molintao (2019) mengatakan bahwa komunikasi terapeutik perawat berpengaruh dan berhubungan secara signifikan terhadap tingkat kecemasan pasien pre operasi. Hal ini didukung oleh Pringgayuda et al. (2020) mengatakan bahwa komunikasi terapeutik perawat yang baik dapat menurunkan kecemasan pasien pre operasi, demikian sebaliknya semakin buruk komunikasi terapeutik yang diberikan oleh perawat akan 
berdampak pada meningkatnya kecemasan pasien.

Hasil penelitian ini berbeda dengan hasil penelitian Loihala et al. (2019) yang menyimpulkan bahwa tidak ada hubungan yang signifikan antara komunikasi terapeutik perawat dengan kecemasan pasien pre operasi di RS Sele Be Solu Kota Sorong. Berdasarkan observasi Loihala et al., ditemukan beberapa faktor yang mungkin dapat menyebabkan penerimaan $\mathrm{H}_{0}$ dalam penelitiannya, yaitu ditemukan perawat di RS Sele Be Solu Kota Sorong telah melakukan komunikasi terapeutik tetapi tidak sesuai dengan langkah-langah (SOP), perawat juga diobservasi tidak menunjukkan rasa empati kepada pasien saat berkomunikasi, perawat hanya berkomunikasi secara terapeutik kepada keluarga dan mengabaikan pasien pre operasi, perawat tidak memiliki persiapan maksimal sebelum menghadapi pasien preoperasi, serta alat ukur atau kuesioner yang digunakan peneliti tidak mengungkapkan intensitas pasien terpapar komunikasi terapeutik dengan perawat.

\section{Kesimpulan dan Rekomendasi}

Gambaran komunikasi terapeutik perawat di Rumah Sakit Advent Medan berdasarkan persepsi pasien pre operasi adalah berada pada kategori yang baik. Sedangkan tingkat kecemasan pasien pre operasi berada pada kategori normal. Melalui uji korelasi, peneliti menyimpulkan bahwa terdapat hubungan signifikan komunikasi terapeutik perawat dengan kecemasan pasien pre operasi di Rumah Sakit Advent medan.

Dalam penelitian ini peneliti menemukan dalam jumlah kecil kemampuan komunikasi yang cukup dan kurang diantara perawat di Rumah Sakit Advent Medan, serta masih ada pasien pre operasi yang mengalami kecemasan ringan hingga sedang dalam jumlah yang kecil. Berdasarkan hal tersebut, peneliti merasa perlu agar dilakukan kajian yang lebih dalam tentang faktor-faktor yang berhubungan dengan kecemasan pada pasien pre operasi, apakah tingkat pengetahuan pasien, tingkat pendidikan, motivasi, pengalaman operasi, dan dukungan keluarga. Perlu juga dikaji tentang faktor-faktor yang menghambat terlaksananya komunikasi terapeutik perawat secara maksimal, seperti faktor internal dan eksternal yakni kepribadian perawat, dukungan dari pimpinan dan rekan kerja, serta beban kerja perawat.
Peneliti merasa kajian ini perlu dilakukan, sebagai upaya untuk meningkatkan pelaksanaan komunikasi terapeutik demi asuhan keperawatan yang berkualitas, baik secara teori maupun pratek, khususnya dalam mengatasi masalah kecemasan pada pasien yang akan menjalani tindakan medis, seperti tindakan operasi.

\section{Daftar Pustaka}

Agustina, \& Oxyandi, M. (2018). Hubungan Komunikasi Terapeutik Perawat dan Dukungan Keluarga dengan Tingkat Kecemasan Pasien Pre Operatif di Ruang Marwah RSI Siti Khadijah Palembang Tahun 2017. Jurnal 'Aisyiyah Medika, 1(2). https://jurnal.stikes-aisyiyahpalembang.ac.id/index.php/JAM/article /download/19/288

Anasril, \& Husaini, M. (2020). Efektivitas Penyuluhan Kesehatan terhadap Penurunan Tingkat Kecemasan Pasien Preoperatif di RSUD Cut Nyak Dhien Meulaboh. Jurnal Serambi Akademica, 8(3), 364-371. http://www.jurnal.serambimekkah.ac.id /serambi-

akademika/article/download/2117/1732

Anggarini, P. (2015). Hubungan Persepsi Pasien Tentang Pelaksanaan Komunikasi Terapeutik Perawat dengan Tingkat Kecemasan Pasien pre operasi di Ruang Flamboyan RSUD Muntilan. STIKES 'Aisyiyah Yogyakarta.

Anggreny, L. O., Lestari, D. R., \& Agustina, R. (2019). Hubungan Sumber Akses Informasi terhadap Tingkat Kecemasan pada Klien Pre Operasi Katarak di Rumah Sakit Mata SMEC Balikpapan. Nerspedia Journal, 2(1), 95-104. http://jtam.ulm.ac.id/index.php/nersped ia/article/view/194/104

Annisa, D. F., \& Ifdil. (2016). Konsep Kecemasan (Anxiety) pada Lanjut Usia. Konselor, 5(2), 1-7.

Asnuriyati, W., \& Wahyu, N. (2019). Gambaran Hubungan Manfaat Komunikasi Terapeutik dan Tingkat Kecemasan Pasien Pre Operatif di RS TK. III DR. R. Soeharsono Banjarmasin. Proceeding of Sari Mulia University Nursing National Seminars, 1(1). 
https://ocs.unism.ac.id/index.php/PRO $\mathrm{KEP} /$ article/view/81

Basra, Muhammad, M., \& Muslimin, Y. (2017). Hubungan Komunikasi Terapeutik Perawat dengan Tingkat Kecemasan Pasien Pre Operasi. Jurnal Ilmiah Kesehatan Pencerah, 6(2), 98102.

Carnegie, D. (2019). Petunjuk Hidup Bebas Stress dan Cemas. Gramedia.

Cholis, E. N., Rumpiati, R., \& Sureni, I. (2020). Hubungan Komunikasi Terapeutik Perawat dengan Tingkat Kecemasan Pasien Hemodialisa di RSUD Dr Harjono Ponorogo. Jurnal Keperawatan Terpadu, 2(1)(26850710), 54-62. http://jkt.poltekkesmataram.ac.id/index.php/home/article/v iew/55/59

Daryanti, E., \& Mardiana, F. (2020). Efektifitas Hypnotherapy dalam Mengurangi Tingkat Kecemasan Pasien Preoperasi Hernia di RS TNI AU dr. M Salamun Bandung 2019. Jurnal Mitra Kencana, 4(1), 24-33. http://jmkubk.id/index.php/jmk kb/arti cle/view/97/89

Fandizal, M., Tobing, D. L., \& Novianti, E. (2020). Kepuasan Klien dengan Komunikasi Terapeutik Perawat Rumah Sakit Kepolisian Pusat Raden Said Soekanto. Jurnal Keperawatan Muhammadiyah, $\quad 5(1)$. http://103.114.35.30/index.php/JKM/art icle/download/4602/2951.

Gunarsah, M. (2019). 17 Trik Mengatasi Kecemasan: Bebas Anxiety. Mantab Jiwah.

Handayani, D., \& Armina. (2017). Faktorfaktor yang Berhubungan dengan Penerapan Komunikasi Terapeutik oleh Perawat pada Pasien di Ruang Rawat Inap Rumah Sakit Umum Daerah Raden Mattaher Jambi. Jurnal Akademika Baiturrahim, 6(2), 1-11. http://jab.stikba.ac.id/index.php/jab/arti cle/download/23/25

Hidayatullah, M. S., Khotimah, H., \& Nugroho, S. A. (2020). Hubungan Komunikasi Terapeutik Dengan Kepuasan Pasien Rawat Inap Puskesmas Tapen Kabupaten Bondowoso. Jurnal Keperawatan Profesional, $\quad 8(1), \quad$ 62-73. https://www.ejournal.unuja.ac.id/index. php/jkp/article/view/1022/530

Hotijah, S. (2019). Hubungan Tingkat Kecemasan dengan Kualitas Tidur pada Mahasiswa Baru Luar Pulau Jawa Universitas Jember. Universitas Jember.

Inayati, A., \& Ayubbana, S. (2017). Hubungan Tingkat Kecemasan dengan Peningkatan Tekanan Darah pada Pasien Praoperasi Elektif di Ruang Bedah. Jurnal Wacana Kesehatan, 1(1), 163-169. http://jurnal.akperdharmawacana.ac.id/i ndex.php/wacana/article/view/43/18

Irwanto, Narmawan, \& Indriastuti, D. (2020). Perbedaan Tanda Vital sebagai Respon Kecemasan pada Pasien Preoperatif. Dunia Keperawatan: Jurnal Keperawatan Dan Kesehatan, 8(1), 2633. https://ppjp.ulm.ac.id/journal/index.php $/ J D K /$ article/download/7251/pdf

Kusmiran, E. (2017). Pelatihan Soft Skills Caring Meningkatkan Kualitas Pelayanan Keperawatan dan Kepuasan Pasien di Rumah Sakit kota Bandung. Jurnal Penelitian Dan Pengembangan Pelayanan Kesehatan, 1(2), 71-81.

Loihala, M., Efake, H. P., \& Mustamu, A. C. (2019). Hubungan Komunikasi Terapeutik dengan Kecemasan Pasien Pre Operasi Katarak. Nursing Arts, 13(2), 117-123. https://poltekkessorong.e-

journal.id/nursingarts/article/view/91/5

Mamahit, A., Molintaao, W., \& Macpal, V. S. (2019). Pengaruh Komunikasi Terapeutik terhadap Tingkat Kecemasan Pasien Pre Operasi Sectio Caesarea di Kamar Bersalin Rumah Sakit Umum Daerah Liunkendage Tahuna. Jurnal of Community and Emergency, 2(2), 178-191. http://ejournal.unpi.ac.id/index.php/JO CE/article/view/206/192

Margianti, D., Rahayu, U., \& Pebrianti, S. (2019). Gambaran Tingkat Kecemasan Preoperative Pada Pasien Dengan Fraktur. Jurnal Keperawatan'Aisyiyah, 6(1), 99-108.

Molintao, W. P. (2019). Hubungan Komunikasi Terapeutik Perawat dengan Tingkat Kecemasan Pasien Pre Operatif di Instalasi Gawat Darurat 
trauma RSUP Prof. DR. R.D Kandou Manado. Journal Of Community and Emergency, 7(1), 55-65. http://ejournal.unpi.ac.id/index.php/JO CE/article/view/145/131

Mundakir. (2016). Buku Ajar Komunikasi Pelayanan Kesehatan (Cetakan 1). Indomedia Pustaka. http://repository.umsurabaya.ac.id/1888/1/Buku_Ajar\%2C Komunikasi_Pelayanan_Kesehatan.pd $\bar{f}$

Nanda, A. S. (2018). Pengaruh Responsiveness Perawat dalam Praktik Komunikasi Terapeutik terhadap Kepuasan Pasien Instalasi Rawat Inap RSU Haji Surabaya. Jurnal Administrasi Kesehatan Indonesia, 6(2), 173-179.

Ndani, S., Sumiatin, T., \& Ningsih, W. T. (2018). Hubungan Dukungan Keluarga dengan Tingkat Kecemasan Lansia Pre Operasi Katarak di Poli Mata RSUD dr. R Koesma Tuban. Jurnal Keperawatan, 11(1), 13-17. http://journal.poltekkesdepkessby.ac.id/index.php/KEP/article/view/1 437

Ningsih, D. A., \& Maryati, S. (2020). Hubungan Pengetahuan dengan Tingkat Kecemasan Pasien Pre Operasi Sectio Caesarea di Rumkit Tk IV 02.0.01 Zainul Arifin Kota Bengkulu. Jurnal Ilmiah Kesehatan Ar-Rum Salatiga, 4(2), 35-41. http://e-journal.arrum.ac.id/index.php/JIKA/article/view/ 93/102

Palla, A., Sukri, M., \& Suwarsi. (2018). Faktor-faktor yang Berhubungan dengan Tingkat Kecemasan Pasien Pre Operasi. Jurnal Ilmiah Kesehatan Pencerah, 7(1), 45-53.

Pandiangan, E., \& Wulandari, I. S. M. (2020). Hubungan Dukungan Keluarga dengan Kecemasan Pasien Pre-Operasi. MANUJU: Malahayati Nursing Journal, 2(3), 469-479. https://core.ac.uk/download/pdf/328113 623.pdf

Pringgayuda, F., Yulianto, A., \& Safirwansyah, A. (2020). Hubungan Komunikasi Terapeutik dengan Tingkat Kecemasan pada Pasien Pre Operasi Benign Prostate Hyperplasia. Jurnal Kesehatan Panca Bhakti Lampung, 3, 93-100.
Putri, D. A. H. (2020). Komunikasi Terapeutik: Strategi Pemulihan Pasien Gangguan (Skizofrenia) Berdasarkan Berspektif Ajaran Agama Hindu Di Rumah Sakit Jiwa Provinsi Bali. Nilacakra.

Rahman, A., \& Pubian, A. K. (2020). Hubungan Kecemasan dengan Gangguan Tidur pada Pasien yang akan Menjalani Operasi. Jurnal Ilmu Keperawatan Indonesia, 1(2), 1-11. http://jurnal.umitra.ac.id/index.php/jikp i/article/view/190/94

Rismawan, W., Rizal, F. M., \& Kurnia, A. (2019). Tingkat Pecemasan pasien PreOperasi di RSUD dr. Soekardjo kota Tasikmalaya. Jurnal Kesehatan Bakti Tunas Husada: Jurnal Ilmu Keperawatan, Analis Kesehatan Dan Farmasi, 19(1), 65-70.

Safitri, W., \& Agustin, W. R. (2020). Terapi Guide Imagery terhadap Penurunan Kecemasan Pasien Preoperasi Sectio Caesarea. Keperawatan 'Aisyiyah, 7(1), 31-37. http://journal.stikesaisyiyahbandung.ac.id/index.php/jka/art icle/view/163/109

Sartika, M., \& Pujiastuti, R. A. (2020). Analisis Tingkat Kecemasan Pasien yang akan Menjalani Tindakan Kateterisasi Jantung di Rumah Sakit Omni Pulomas Jakarta Timur. Jurnal Ilmu Kesehatan Indonesia (JIKSI), 1(1), 1-9. http://www.jurnal.umitra.ac.id/index.ph p/JIKSI/article/view/377/266

Sugiyono. (2018). Metode Penelitian Pendidikan: Pendalaman Kualitatif, dan $R \& D$. Alfabeta.

Sulastri, Trilianto, A. E., \& Ermaneti, Y. (2019). Pengaruh Komunikasi Terapeutik Perawat terhadap Tingkat Kecemasan pada Pasien Pre Operasi. Jurnal Keperawatan Profesional, 7(1). https://ejournal.unuja.ac.id/index.php/jk p/article/view/503/338

Sutrisno, T. A., \& Suroso, J. (2020). Hubungan Komunikasi Terapeutik dan Kualitas Pelayanan Perawat dengan Kecemasan Pasien Pre Operasi di RSUD Dr. R. Goeteng Taroenadibrata Purbalingga. Jurnal Keperawatan Muhammadiyah, 31-38. http://journal.umsurabaya.ac.id/index.php/JKM/article/d 
ownload/5194/3132

Suyitno, A., Wihastuti, T. A., \& Supriati, L. (2017). Analisis Faktor-faktor yang Berhubungan dengan Pelaksanaan Komunikasi Terapeutik Perawat di PICU RSJ Dr. Radjamin Wediodiningrat Lawang. J.K.Mesencephalon, 3(2), 68-73.

Talindong, A., \& Minarsih, M. (2020). Pengaruh Pelayanan Kebutuhan Spiritual terhadap Tingkat Kecemasan Pasien Pre Operasi di Rumah Sakit Woodward. Jurnal Ilmiah Kesmas-IJ, 20(1), 64-72. http://journal.stikij.ac.id/kesmas/article/view/56/45

Tridiyawati, F., Idealistiana, L., \& Rofita. (2020). Hubungan Komunikasi Terapeutik Perawat terhadap Tingkat Kecemasan Keluarga Pasien. Jurnal Antara Kebidanan, 3(2), 109-112. http://ojs.abdinusantara.ac.id/index.php /antarakebidanan/article/download/167/ 150

Vellyana, D., Lestari, A., \& Rahmawati, A. (2017). Faktor-faktor yang Berhubungan dengan Tingkat Kecemasan pada Pasien Preoperative di RS Mitra Husada Pringsewu. Jurnal Kesehatan, 8(1), 108-113.

Wianti, A. (2017). Gambaran Pelaksanaan Komunikasi Terapeutik pada Pasien Pre Operasi di Ruang Dadali RSUD Cideres Kabupaten Majalengka Tahun 2016. Jurnal Kampus SKITES YPIB Majalengka, 5(2), 15-22. http://ejournal.stikesypib.ac.id/index.php/JK/ar ticle/view/78 